\title{
Ortaokul Öğrencilerinin “Güneş Sistemi” İle İlgili Zihinsel Modelleri*
}

\author{
Secondary School Students' Mental Models about “Solar System” \\ Meryem Görecek Baybars ${ }^{\mathrm{a}, * *}$, Mustafa Çi1 ${ }^{\mathrm{b}}$ \\ ${ }^{a}$ Dr. Öğr. Üyesi, Muğla Sttkı Koçman Üniversitesi, Eğitim Fakültesi, Matematik ve Fen Bilimleri Eğitimi Bölümü, 48000, Muğla/Türkiye. \\ ORCID: 0000-0002-8942-7590

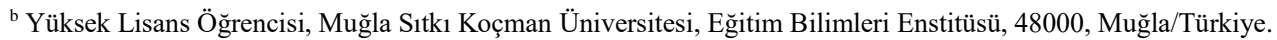

MAKALE BİLGİSİ
Makale Geçmişi:
Başvuru tarihi: 04 Şubat 2019
Küzeltme tarihi: 28 Nisan 2019
Kabul tarihi: 14 Mayıs 2019
Anahtar Kelimeler:
Astronomi
Güneş sistemi
Zihinsel model

\section{A R T I C L E IN F O}

Article history:

Received 04 February 2019

Received in revised form 28 April 2019

Accepted 14 May 2019
ÖZ

$\mathrm{Bu}$ araştırmanın amacı ortaokul öğrencilerinin "Güneş sistemi” ile ilgili zihinsel modellerinin belirlenmesidir. Araştırma, 2017-2018 eğitim-öğretim yılı bahar döneminde Türkiye'nin batı bölgesinde yer alan iki devlet okulunun tüm ortaokul öğrencileri ile gerçekleştirilmiş olup, araştırmaya toplam 340 öğrenci katılmıştır. Araştırmada kullanılan veri toplama aracı, iki açı1k uçlu sorudan oluşmaktadır. Veri toplama aracında yer alan sorular, öğrencilerin Güneş sistemini betimleme ve görselleme durumlarını ortaya çıkaracak şekilde hazırlanmıştır. Veri analizinde, öncelikle öğrencilerin Güneş sistemini betimleme ve görselleme durumları ayrı ayrı analiz edilmiş, sonra betimleme ve görselleme sorularına verilen cevaplar birlikte değerlendirilerek öğrencilerin zihinsel modelleri belirlenmiştir. Araştırma sonucunda ortaokul öğrencilerinin "Güneş sistemi” ile ilgili bilimsel zihinsel modele sahip olmadığı, öğrencilerin daha çok sentez ve ilkel model düzeyinde zihinsel modele sahip olduğu sonucuna ulaşılmıştır.

\section{Keywords:}

Astronomy

Solar System

Mental Model

\section{A B S T R A C T}

The purpose of this study is to determine secondary school students' mental models about the "Solar System". The study was conducted on all the students attending two state middle schools located in the western part of Turkey in the spring term of 2017-2018 school year and a total of 340 students participated in the study. The data collection tool used in the study consists of two open-ended questions. The questions in the data collection tool were developed to elicit the students' states of describing and visualizing the solar system. In the analysis of the collected data, first the students' states of describing and visualizing the solar system were separately analyzed and then the students' responses given to the description and visualization questions were evaluated together and thus their mental models were determined. As a result of the study, it was concluded that secondary school students did not have scientific mental models about the "Solar System" and they mostly had mental models at the initial and synthesis models.

\section{Giriş}

Fen alanında yer alan temel kavramlar incelendiğinde, bu kavramlardan bazılarının günlük yaşamda karşılaştığımız ve her gün deneyimlediğimiz kavramlardan oluştuğu görülmektedir. Bunun yanı sıra bazı kavramlar ise günlük yaşantıda deneyimleme şansımız olmayan kavramlardır ve bu kavramları görme ya da örnekleme şansımızda yoktur. Bu noktada yardımımıza koşan temel unsurlar arasında modeller ilk sırada yer alır. Modeller, Ünal-Çoban (2009) tarafindan bilinen bir olaydan yola çıkarak bilinmeyen ya da daha soyut olanı anlatan, olay ya da sistemler olarak tanımlanırken,

\footnotetext{
* Bu çalışma, 4-6 Ekim 2018 tarihlerinde Denizli’de düzenlenen 13. Ulusal Fen Bilimleri ve Matematik Eğitimi Kongresi’nde bildiri olarak sunulmuştur.

** Sorumlu yazar/Corresponding author.

e-posta:mgorecek@mu.edu.tr
} 
Harrison'a (2001) göre modeller, bilimsel bir bilgi ile gerçekler arasında ilişki kuran, karmaşık yapıları en basit hale getiren temsiller olarak ifade edilmektedir. Alan yazında farklı tanımlar olsa da, kullanılan modeller teori ile olgular arasında anlamlı ilişkilerin kurulmasını sağlar (Greca ve Moreira, 2000). Alan yazın incelendiğinde, modellerin farklı şekillerde sınıflandırıldığı görülmektedir. Örneğin, Harrison ve Treagust (2000), modelleri dört ana başlik altında; (1)gerçeklik teori ve süreçlerin kişisel modelleri, (2) çoklu kavram süreçleri gösteren modeller, (3) pedagojik analojik modeller ve (4) bilimsel modeller olarak ele alırken, Örnek (2008) kavramsal ve zihinsel modeller olmak üzere iki başlık altında toplamıştır.

Zihinsel modeller, bilişsel işlemler sırasında bireylerin oluşturduğu zihinsel temsillerdir (Vosniadou, 1994). Bireylere düşüncelerini kullanırken rehberlik eden zihinsel modeller (Norman, 1983), bireylerin hafizalarını daha verimli kullanmalarını da sağlarlar (Coll ve Treagust, 2003). Zihinsel modeller, üretkendir, çünkü yeni bilgilerin tanımlanmasında ve üretilmesinde yol göstericidir, zihinsel modeller, dinamik yapıdadırlar, yeni bilgiler eklendikçe değişsebilirler, bireylerin dünya görüşü ile sınırlıdır çünkü bilgi, deneyim ve inançlardan etkilenirler, ayrıca zihinsel modeller, örtük bilgi içerirler (Franco ve Colinvaux, 2000).

Alan yazın incelendiğinde, bireylerin zihinsel modellerinin tespiti ile ilgili farklı yöntemlerin kullanıldığı görülmektedir (Görecek-Baybars, 2018; Can ve Görecek-Baybars, 2018; Ayvac1, Bebek, Atik, Keleş ve Özdemir, 2016; Demircioğlu, Vural ve Demircioğlu, 2013; Kurnaz, Tarakçı, Aydın ve Pektaş, 2013; Yürümezoğlu ve Çökelez, 2010; Jabot ve Henry, 2007; Coll ve Tregaust, 2003; De Posada, 1997; Kibble, 1999, Vosniadou ve Brewer, 1992). Bu çalışmalar incelendiğinde, daha çok çizim ve açıklama içeren açık uçlu sorular, çoktan seçmeli sorular ve görüşmelerin kullanıldığ görülmektedir.

Alan yazın incelendiğinde astronomi konuları ve zihinsel modellerin birlikte ele alındığı pek çok çalışma mevcuttur (Can ve Görecek-Baybars, 2018; Çelik ve Tekbıyık, 2016; İyibil, 2010; İyibil ve Sağlam-Arslan, 2010; Kurnaz ve Değermenci, 2012; Vosniadou ve Brewer, 1992). Vosniadou ve Brewer (1992), çalışmalarında öğrencilerin Dünya'nın şekli ile ilgili zihinsel modellerini belirlemeye çalışmışlardır. Çalışma sonucunda bazı öğrencilerin bilimsel modellerden küresel modele sahip olduğu, bazı öğrencilerin ise dikdörtgen ve yassı disk modeline sahip olduğu belirlenmiştir. Kurnaz ve Değermenci (2012), özel durum yöntemi ile yürüttükleri çalışmalarında güneş-dünya-ay sistemi ile ilgili yedinci sınıf öğrencilerinin zihinsel modellerini belirlemeye çalışmışlardır. Çalışma sonucunda yedinci sınıf öğrencilerinin daha çok sentez model düzeyinde zihinsel modellere sahip olduğu belirlenmiştir. Çelik ve Tekbıyık (2016), çalışmalarında, ilkokul ikinci sınıf öğrencilerinin dünya ve uzay kavramlarına yönelik zihinsel modellerini belirlemeye çalışmışlardır. Çalışma toplam 114 öğrenci ile gerçekleştirilmiş olup, içerik bilgisi zihin haritası ile yapı bilgisi ve imajları çizim ile ve işlemsel bilgiler görüşmeler ile belirlenmeye çalışılmıştır. Can ve GörecekBaybars (2018) çalışmalarında, ortaokul öğrencilerinin uzay ile ilgili zihinsel modellerini belirlemeye çalışmışlardır. Çalışmada çizim ve açıklama gerektiren dört adet açık uçlu soru kullanılmıştır. Çalışma sonucunda uzay ile ilgili altı farklı zihinsel model tespit edilmiş olup, en sık gözlenen zihinsel modeller ise gök cisimleri modeli ve uzay araştırmaları modeli olmuştur. İyibil ve Sağlam-Arslan (2010), çalışmalarında fizik öğretmen adaylarının yıldız kavramına ilişkin zihinsel modellerini belirleyebilmek için dört açık uçlu sorudan oluşan bir veri toplama aracı geliştirmişlerdir. Çalışma sonucunda öğretmen adaylarının yıldız kavramına dair dört farklı zihinsel modele sahip olduğu belirlenmiştir. Bu modellerden biri bilimsel, biri ilkel ikisi ise sentez model kategorisinde değerlendirilmiştir.

Alan yazında yer alan çalışmalar değerlendirildiğinde, daha çok yıldız, gezegen, dünya-güneş-ay ve uzay kavramlarına değinildiği, bazı çalışmalarda bütün kavramların yer aldığı bazı çalışmalarda ise kavramların tek tek ele alındığı görülmektedir. Ancak güneş kavramı her ne kadar alan yazında yer alan çalışmalar içerisinde yer alsa da (Babaoğlu ve Keleş, 2018; Yılmaz, Türkoğuz ve Şahin, 2014;), Güneş sistemi (Calderon-Canales, Flores-Camacho ve GallegosCazares, 2013; Sharp ve Kuerbis, 2005; Sharp, 1996) ile ilgili çalışma sayısı oldukça azdır. Sharp (1995) tarafından gerçekleştirilen çalışmada, gezegenlerin uzayın temel yapı taşı olduğu ve öğrencilerin açıklamalarında 3-4 gezegen ismi üzerinde durduğu ve en çokta Jüpiter gezegenine değindiği sonucu ortaya çıkmıştır. Çalışmada dikkat çeken bir diğer sonuç ise öğrencilerin sadece gözleyebildikleri (güneş, ay, yıldız) nesneler hakkında bir şeyler bildikleridir. CalderonCanales vd. (2013) çalışmalarında öğrencilere Güneş sisteminin ne olduğunu biliyor musunuz? sorusunu yöneltmişler ve cevaplarda gezegenlerin sıralamasıdır açıklaması en sık rastlanan açıklama olmuştur. Bazı öğrenciler ise güneşi, ayı ve dünyayı içeren gezegen gruplarıdır açıklamasında bulunmuşlardır. Çalışmanın devamında öğrencilerden istedikleri kadar top kullanarak Güneş sistemi ile ilgili bir model oluşturmaları istenmiştir. Öğrenciler tarafından oluşturulan modellerde 7 farklı model dikkat çekmektedir. $\mathrm{Bu}$ modellerden en sık karşılaşılanı Güneşin bir uçta, gezegenlerin ise düz bir çizgi boyunca dağıldığı sıralamadır. Bu model Sharp ve Kuerbis (2005) tarafından gerçekleştirilen çalışmada da en sık karşılaşılan model olmuştur. Alan yazında, astronomi alanında gerçekleştirilen çalışmalar incelendiğinde, bireylerin astronomi kavramlarına ait bilgileri sadece ders kitaplarından elde etmediği sonucu da ortaya konulmuştur. Çelik ve Tekbıyık (2016), çalışmalarında öğrencilerin zihinsel modellerinin oluşmasında TV programlarının, okulda öğretilen derslerin ve hikâye kitaplarının etkili olduğu sonucuna ulaşmıştır. Ayrıca Avrupa Astronomi Birliği (EAAE) (1994)'te bireylerin TV programlarından veya diğer yayın organlarından astronomi ile ilgili pek çok yanlış bilgi edindiğini ortaya koymuştur. Benzer şekilde Can ve Görecek-Baybars (2018) tarafından gerçekleştirilen çalışmada da, internet, okul, ders kitapları ve TV programları öğrencilerin astronomi kavramlarına ait bilgi kaynaklarında ilk sırada yer almıştır.

Türk Fen bilimleri dersi öğretim programı (2018), incelendiğinde, bireylere astronomi hakkında temel bilgiler kazandırmak programın temel amaçları arasında yer almakta olup, astronomi ile ilgili konular ilkokul üçüncü sınıf programında Dünya ve evren konu alanı altında "Gezegenimizi Tanıyalım" ünitesi ile başlamaktadır. Öğrencilerin Güneş kavramı ile program kapsamında ilk defa karşılaşmaları ise beşinci sınıf "Güneş, Dünya ve Ay" ünitesi kapsamında olup, altıncı sınıfta, "Güneş sistemi ve Tutulmalar", yedinci sınıfta ise "Güneş sistemi ve ötesi" 
üniteleri ile devam etmektedir. Altıncı sınıfta yer alan "Güneş sistemi ve tutulmalar" ünitesi kapsamında öğrencilere Güneş sistemi, gezegen, meteor, gök taş1 ve asteroit kavramları verilmekte olup, öğrencilerin Güneş sistemini modellemeleri beklenmektedir. Altıncı sınıfta yer alan bu kavramların doğru bir şekilde öğrenilmesi, sonraki yıllarda Güneş sistemi ile doğrudan ilişkili olsun olmasın astronomi ile ilgili diğer kavramların anlaşılmasına da temel oluşturacağı düşünülmektedir. Astronomi ile ilgili kavramlar ele alındığında Güneș Sistemi’nin oldukça önemli bir yere sahip olduğu görülmektedir. Çünkü Güneş sistemi kavramının anlaşılması ile öğrenci güneş, yıldız, uydu, gezegen, yörünge, meteor vb. pek çok kavram hakkında bilgi sahibi olabilmektedir. Tüm bu noktalar dikkate alındığında, öğrencilerin Güneş sistemi ile ilgili zihinsel modellerinin ne olduğunun ortaya konulması ayrı bir önem kazanmaktadır. Ayrıca araştırmadan elde edilecek bulguların, bundan sonra gerçekleştirilecek çalışmalara ve öğretmenlere bilgi kaynağı oluşturacağı düşünülmektedir. Bu nedenle bu araştırmanın amac1, ortaokul öğrencilerinin Güneş sistemi ile ilgili zihinsel modellerinin belirlenmesidir.

\section{Yöntem ve Uygulama}

Araştırmanın yöntem başlığı altında araştırmanın modeli, evren ve örneklem, veri toplama arac1, veri toplama süreci ve analizi konularına değinilmiştir.

$\mathrm{Bu}$ araştırmada betimsel tarama modeli kullanılmıştır. Tarama çalışmalarında, araştırmacı, çalışmaya konu olan birey, olay veya nesneyi kendi koşulları içinde, herhangi bir deneysel müdahalede bulunmadan, oldukları gibi tanımlamaya çalışır (Karasar, 2011). Bu araştırma kapsamında da, araştırmacılar, ortaokul öğrencilerinin Güneş sistemi ile ilgili zihinsel modellerini, herhangi bir deneysel işlem gerçekleştirmeden, kendi mevcut koşulları içinde belirlemeyi amaçlamışlardır.

Araştırmada, zaman ve ulaşılabilirlik durumu göz önünde bulundurularak, kolay ulaşılabilir örnekleme yöntemi kullanılmıştır. Kolay ulaşılabilir örnekleme yöntemi ayrıca, araştırmaya hız ve pratiklik kazandırır (Yıldırım ve Şimşek, 2008). Araştırmanın evrenini, 2017-2018 eğitim-öğretim yılı bahar döneminde Türkiye'nin batı bölgesinde, bir il merkezinde yer alan, tüm ortaokullardaki öğrenciler, örneklemini ise belirtilen il merkezinde bulunan iki devlet okulunun tüm ortaokul öğrencileri oluşturmaktadır. Araştırmaya toplam 340 öğrenci katılmıştır.

Araştırmada iki açık uçlu sorudan oluşan veri toplama aracı kullanılmıştır. Veri toplama aracı, öğrencilerin Güneş sistemini betimleme (1.soru) ve görselleme (2.soru) durumlarını ortaya çıkaracak şekilde hazırlanmıştır. Bir fen bilgisi öğretmeninden ve bir fizik eğitimi alanında çalışan öğretim üyesinden uzman görüşü alınarak, çalışma grubundan farklı 30 sekizinci sınıf öğrencisine pilot uygulama yapılmıştır. Pilot uygulama sonucunda, veri toplama aracının açık ve anlaşılır olduğu ve cevaplanması için 15 dakikanın yeterli olduğu görülmüştür. Veri toplama aracında yer alan sorular aşağıda sunulmuştur.

1.Güneş sistemi” denilince aklınıza neler gelmektedir? Açıklayınız.
2.Güneş sisteminin nasıl bir şekle sahip olduğunu düşünüyorsunuz? Çizerek açıklayınız. Çizdiğiniz resimde gökcisimlerini belirtiniz.

Araştırmanın asıl uygulaması için belirlenen okulların idarecileri ve fen bilgisi öğretmenleri ile görüşülmüş ve araştırma hakkında bilgi verilmiştir. Öğretmenler ile beraber veri toplama aracının uygulama planı oluşturulmuş ve araştırmanın ikinci yazarı tarafından bu plan çerçevesinde okullara gidilerek uygulama gerçekleştirilmiştir. Araştırmacı, öğrencilere araştırma hakkında bilgi vermiş, elde edilen verilerin nasıl ve ne amaçla kullanılacağını açıklamış, özellikle çizim sorusunda çizimlerin güzel veya çirkin olmasının önemli olmadığı vurgusu yapılmıştır. Veri toplama aşamasında, araştırmaya katılan öğrencilerin veri toplama aracını eksiksiz ve özenle doldurmaları sağlanmıştır.

Veri analizinde, nitel olarak, öğrencilerin betimleme ve görselleme durumları ayrı ayrı analiz edilmiştir. Daha sonra ögrencilerin, veri toplama aracında yer alan 1. ve 2.soruya verdikleri cevaplar birlikte değerlendirilerek, zihinsel modeller belirlenmiştir. Zihinsel modeller, alanyazında yer alan ilkel, sentez ve bilimsel modele göre değerlendirilmiştir. Zihinsel modellerin belirlenmesinde kullanılan kategoriler Tablo 1'de sunulmuştur. Tablo 1 incelendiğinde, öğrenci cevaplarında, Güneş sistemi ile ilgili, bilimsel bir betimleme ve bilimsel bir görselleme yapılmış ise model kategorisinin, bilimsel model olarak nitelendirildiği görülmektedir. Tablo 1 incelendiğinde, öğrenci cevaplarında, Güneş sistemi ile ilgili, bilimsel olmayan bir betimleme ve bilimsel olmayan bir görselleme yapılmış ise model kategorisinin ilkel model olarak nitelendirildiği görülmektedir. Tablo 1 incelendiğinde, öğrenci cevaplarında, Güneş sistemi ile ilgili, betimleme ve görselleme durumlarından biri bilimsel değil ise, model kategorisinin sentez model olarak nitelendirildiği görülmektedir. Alan yazında, ilkel model, bireyin bilimsel olmayan fikirlerini, bilimsel model bireyin bilimsel olan fikirlerini, sentez model, bireyin sahip olduğu ilkel modelle, tecrübe ve öğretim süreci boyunca edindiği bilgiler sonucunda sentezlediği model olarak ifade edilmiştir. (Vosniadou ve Brewer, 1992; Kurnaz ve Değermenci, 2012; Saçkes ve Korkmaz, 2015).

Tablo 1. Zihinsel modellerin belirlenmesinde kullanılan kategoriler

\begin{tabular}{|c|c|c|}
\hline $\begin{array}{l}\text { Model } \\
\text { kategorisi }\end{array}$ & Betimleme Durumu & Görselleme Durumu \\
\hline $\begin{array}{l}\text { Bilimsel } \\
\text { Model }\end{array}$ & $\begin{array}{l}\text { Kavram hakkında } \\
\text { bilimsel bilgi içeren } \\
\text { betimlemelerin } \\
\text { yapılması }\end{array}$ & $\begin{array}{l}\text { Kavram hakkında bilimsel } \\
\text { bir çizim yapılması }\end{array}$ \\
\hline $\begin{array}{l}\text { Sentez } \\
\text { Model }\end{array}$ & $\begin{array}{l}\text { Kavram hakkında } \\
\text { bilimsel bilgi içeren } \\
\text { betimlemelerin } \\
\text { yapılması } \\
\text { Kavram hakkında } \\
\begin{array}{l}\text { bilimsel olmayan } \\
\text { betimlemelerin } \\
\text { yapılması }\end{array}\end{array}$ & $\begin{array}{l}\begin{array}{l}\text { Kavram hakkında } \\
\text { olmayan bilimsel } \\
\text { yapılması }\end{array} \\
\text { çizimin } \\
\text { Kavram } \\
\text { hakkında bilimsel bir çizim } \\
\text { yapılması }\end{array}$ \\
\hline $\begin{array}{l}\text { İlkel } \\
\text { Model }\end{array}$ & $\begin{array}{l}\text { Kavram hakkında } \\
\text { bilimsel olmayan } \\
\text { betimlemelerin } \\
\text { yapılması }\end{array}$ & $\begin{array}{l}\text { Kavram hakkında bilimsel } \\
\text { olmayan bir çizim yapılması }\end{array}$ \\
\hline
\end{tabular}




\section{Bulgular}

Araştırmadan elde edilen bulgular "öğrencilerin betimleme durumları", "öğrencilerin görselleme durumları" ve "öğrencilerin zihinsel modelleri” olmak üzere üç başlık altında sunulmuştur. Araştırmadan elde edilen bulguların belirtildiği şekilde üç başlık altında sunulması daha önce Kurnaz ve Değermenci (2012) tarafindan gerçekleştirilen çalışmada kullanılmıştır.

\section{Öğrencilerin Güneş Sistemi’ni Betimleme Durumları}

Veri toplama aracında yer alan birinci soru öğrencilerin Güneş Sistemi'ni betimleme durumları ile ilgilidir. Birinci sorunun analizinden elde edilen bulgular Tablo 2'de sunulmuştur. Tablo 2 incelendiğinde, 340 ortaokul öğrencisinden 80 öğrencinin Güneş Sistemi’ni betimlerken "gezegen" kavramını kullandığı görülmektedir. Bu 80 öğrencinin 9'u beşinci sınıf, 22'si altıncı sınıf, 19'u yedinci sinıf ve 30'u sekizinci sinıfa devam etmektedir. Tablo 2 incelendiğinde, betimlemelerinde "Güneş etrafında belirli yörüngede dönen gezegenler" ifadesini kullanan öğrenci sayıs1 61'dir. Bu öğrencilerin 21'i sekizinci sınıf, 22'si yedinci sınıf, 14'ü altıncı sınıf ve 4'ü beşinci sınıf öğrencisidir. Güneş Sistemi betimlemelerinde "gezegen isimlerini” kullanan öğrenci sayısı ise 26'dır. Bu öğrencilerin 6's1 sekizinci sınıfa devam ederken, 9'u yedinci sınıf, 8'i altıncı sınıf ve 3'ü beşinci sınıfa devam etmektedir. Tablo 2 incelendiğinde 52 öğrencinin Güneş sistemini betimlerken "Güneş" kavramını kullandığı görülmektedir. $\mathrm{Bu}$ öğrencilerin sınıflara göre dağılımı 10 beşinci sınıf, 18 altıncı sınıf, 8 yedinci sınıf ve 16 sekizinci sınıf şeklindedir. Tablo 2 incelendiğinde "gezegenlerin siralamasıdır" açıklamasını yapan öğrenci sayısının 21 olduğu görülmektedir. Bu cevabın 8.sınıfta yoğunlaştığ1 görülmekte olup, 4 öğrenci 6. sınıf, 5 öğrenci 7.sınıf ve 14 öğrenci ise 8.sınıfa devam etmektedir. Güneş sistemini betimlerken "gezegen topluluğudur" ifadesini kullanan öğrenci sayısı 19'dur. Bu cevapların 7.sınıfta yoğunlaştığı görülmekte olup, 19 öğrenciden 13'ü 7.sınıfa, 4'ü 8.sınıfa ve 2'si ise 5.sınıfa devam etmektedir. Tablo 2 incelendiğinde öğrencilerin Güneş sistemini betimlerken daha az oranda, "uzay, evren, 1sı ve 1şık, uydu, güneş enerjisi (evlerde kullanılan) ve atomun yapisina benzemesi" ifadelerini kullandığ 1 görülmektedir. Tablo 2 incelendiğinde 340 öğrenciden 53 öğrencinin bu soruda herhangi bir cevap vermediği görülmektedir.

Tablo 2. Öğrencilerin Güneş Sistemi’ni Betimleme Durumları

\begin{tabular}{|c|c|c|c|c|c|c|c|c|}
\hline \multirow[b]{2}{*}{ Öğrenci Cevapları } & \multicolumn{2}{|c|}{ 5.sinif } & \multicolumn{2}{|c|}{ 6. sinif } & \multicolumn{2}{|c|}{ 7. sinif } & \multicolumn{2}{|c|}{ 8.sinif } \\
\hline & $\mathrm{f}$ & $\%$ & $\mathrm{f}$ & $\%$ & $\mathrm{f}$ & $\%$ & $\mathrm{f}$ & $\%$ \\
\hline Gezegen & 9 & 17,6 & 22 & 23,2 & 19 & 20,9 & 30 & 29,1 \\
\hline Güneş etrafinda belirli yörüngede dönen gezegenler & 4 & 7,8 & 14 & 14,7 & 22 & 24,2 & 21 & 20,4 \\
\hline Güneş & 10 & 19,6 & 18 & 18,9 & 8 & 8,8 & 16 & 15,5 \\
\hline Gezegen isimleri & 3 & 5,9 & 8 & 8,4 & 9 & 9,9 & 6 & 5,8 \\
\hline Gezegenlerin sıralaması & - & - & 4 & 4,2 & 5 & 5,5 & 12 & 11,7 \\
\hline Gezegen topluluğu & 2 & 3,9 & - & - & 13 & 14,3 & 4 & 3,9 \\
\hline Uzay & 3 & 5,9 & 3 & 3,6 & 5 & 5,5 & - & - \\
\hline Evren & 2 & 3,9 & 4 & 4,2 & - & - & 3 & 2,9 \\
\hline Isı ve Iş1k & 4 & 7,8 & 3 & 3,2 & - & - & - & - \\
\hline Uydu & 2 & 3,9 & 4 & 4,2 & - & - & - & - \\
\hline Güneş enerjisi & - & - & 3 & 3,2 & - & - & - & - \\
\hline Atomun yapısına benzediği & - & - & - & - & 1 & 1,1 & - & - \\
\hline Cevapsiz & 14 & 27,5 & 16 & 16,8 & 13 & 14,3 & 10 & 9,7 \\
\hline
\end{tabular}

\section{Öğrencilerin Güneş Sistemi’ni Görselleme Durumları}

Veri toplama aracında yer alan ikinci soru öğrencilerin Güneş Sistemi'ni görselleme durumları ile ilgilidir. İkinci sorunun analizinden elde edilen bulgular Tablo 3 'te sunulmuştur.
Tablo 3 incelendiğinde, çalışmaya katılan 340 öğrenciden 50 'sinin “Güneş etrafında dağınık gezegen çizimi” yaptığı görülmektedir. $\mathrm{Bu}$ kategoride değerlendirilen çizimlerin19'u altıncı sınıf öğrencisine, 18'i yedinci sınıf öğrencisine, 13'ü ise sekizinci sınıf öğrencisine aittir.

Tablo 3. Öğrencilerin Güneş Sistemi'ni Görselleme Durumları

\begin{tabular}{|c|c|c|c|c|c|c|c|c|}
\hline & \multicolumn{2}{|c|}{ 5.sinif } & \multicolumn{2}{|c|}{ 6.sinif } & \multicolumn{2}{|c|}{ 7.sinif } & \multicolumn{2}{|c|}{ 8.sinif } \\
\hline Öğrenci çizim kategorileri & $\mathrm{f}$ & $\%$ & $\mathrm{f}$ & $\%$ & $\mathrm{f}$ & $\%$ & $\mathrm{f}$ & $\%$ \\
\hline Güneş etrafında dağınık gezegen çizimi & - & - & 19 & 20 & 18 & 19,8 & 13 & 12,6 \\
\hline Güneş merkezli yörünge çizimi & - & - & 15 & 15,8 & 21 & 23,1 & 13 & 12,6 \\
\hline Üçlü model çizimi & 2 & 3,9 & 14 & 14,7 & 10 & 11 & 11 & 10,7 \\
\hline Güneş şekli çizimi & 10 & 19,6 & 5 & 5,3 & 3 & 3,3 & 12 & 6,8 \\
\hline Gezegen çizimi & - & - & 6 & 6,3 & 11 & 12,1 & 6 & 5,8 \\
\hline Güneş sistemi modeli çizim & - & - & 5 & 5,3 & 11 & 12,1 & 6 & 5,8 \\
\hline Güneş etrafinda düz hat boyunca sıralanmış gezegen çizim & - & - & 4 & 4,2 & 8 & 8,8 & 7 & 6,8 \\
\hline Güneş enerjisi paneli çizimi & - & - & 4 & 4,2 & 2 & 2,2 & 9 & 8,7 \\
\hline Yörünge çizimi & - & - & 5 & 5,3 & 1 & 1,1 & 5 & 4,9 \\
\hline Yuvarlak çizimi & - & - & 3 & 3,2 & - & - & 7 & 6,8 \\
\hline Anlamsız çizim & 19 & 37,2 & 7 & 7,4 & - & - & 8 & 7,8 \\
\hline Çizim yok & 20 & 39,2 & 10 & 10,5 & 6 & 6,6 & 8 & 7,8 \\
\hline
\end{tabular}


Bu kategoride değerlendirilen çizimlerde öğrencilerin güneşin etrafında rastgele konumlanmış gezegenler çizdikleri görülmektedir. Bu kategoride değerlendirilen çizimlere örnek aşağıda sunulmuştur.

\section{Ö164 (7.sınıf): Güneş etrafında dağınık gezegen çizimi}

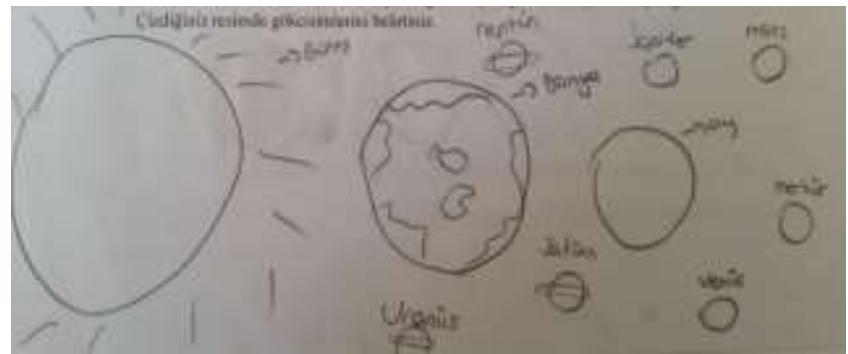

Tablo 3 incelendiğinde, 340 ortaokul öğrencisinden 49 öğrencinin Güneş sistemini görsellerken "güneş merkezli yörünge çizimi'nden yararlandığı görülmektedir. Güneş merkezli yörünge çizimi yapan öğrencilerden, 15'i altıncı sınıf, 21'i yedinci sınıf ve 13'ü sekizinci sınıf öğrencisidir. Bu kategoride çizim yapan öğrencilerin güneşi merkezde çizdiği güneş etrafında yörüngeleri çizdiği ancak güneş sisteminde yer alan gök cisimlerini çiziminde kullanmadığ 1 görülmektedir. $\mathrm{Bu}$ kategoride değerlendirilen çizimlere örnek aşağıda sunulmuştur.

\section{Ö301 (8.sınıf): Güneș merkezli yörünge çizimi}

Tablo 3 incelendiğinde, 340 ortaokul öğrencisinden 37 öğrencinin Güneş sistemini görsellerken "Güneş-dünya-ay çizimi” yaptığı görülmektedir. Bu çizim "üçlü model çizimi”" olarak adlandırılmıştır. Bu kategoride yer alan 37 öğrencinin 2'si beşinci sınıf, 14'ü altıncı sınıf, 10'u yedinci sınıf ve 11'i de sekizinci sınıf öğrencisidir. Bu kategoride değerlendirilen çizimlere örnek aşağıda sunulmuştur.

\section{Ö11 (5.sınıf): Üçlü model çizimi}

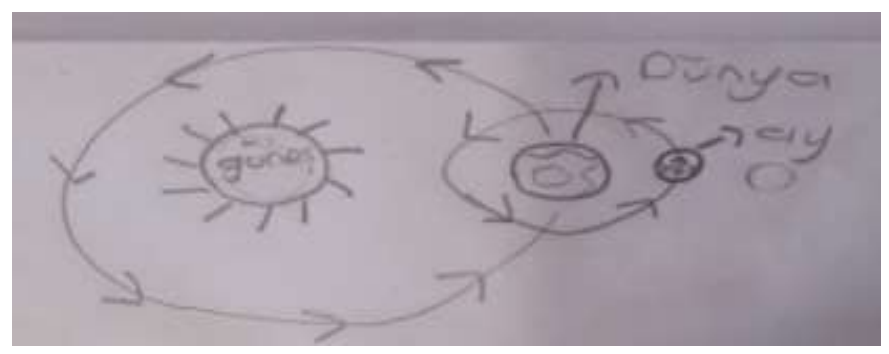

Tablo 3 incelendiğinde, 340 öğrenciden, 30 öğrencinin sadece "güneş" çizdikleri görülmektedir. Bu otuz öğrencinin 10'u beşinci sınıf, 5'i altıncı sınıf, 3'ü yedinci sınıf ve 12'si ise sekizinci sınıf öğrencisidir. Bu kategoride değerlendirilen çizimlere örnek aşağıda sunulmuştur.

\section{Ö96 (6.sınıf): Güneş Çizimi}

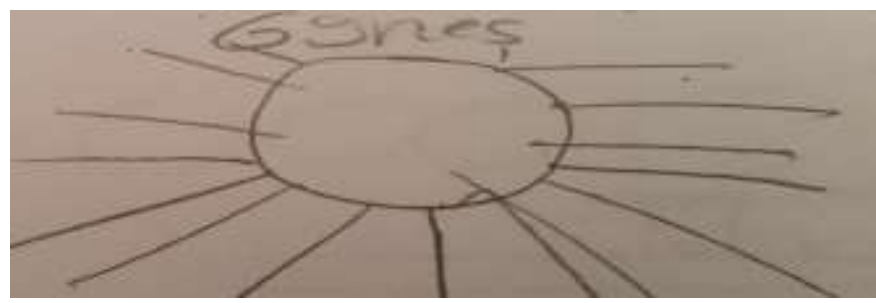

Tablo 3 incelendiğinde, "gezegen çizimi” yapan öğrenci sayısı 23 'tür. Bu kategoride değerlendirilen çizimlerin 6's1 altınc1 sınıf, 11'i yedinci sınıf ve 6'sı sekizinci sınıf öğrencisidir. Bu çizimlerde öğrencilerin sıklıkla Jüpiter, Satürn, Mars ve Dünya'ya yer verdiği görülmektedir. $\mathrm{Bu}$ kategoride değerlendirilen çizimlere örnek aşağıda sunulmuştur.

\section{Ö200 (7.sınıf): Gezegen Çizimi}

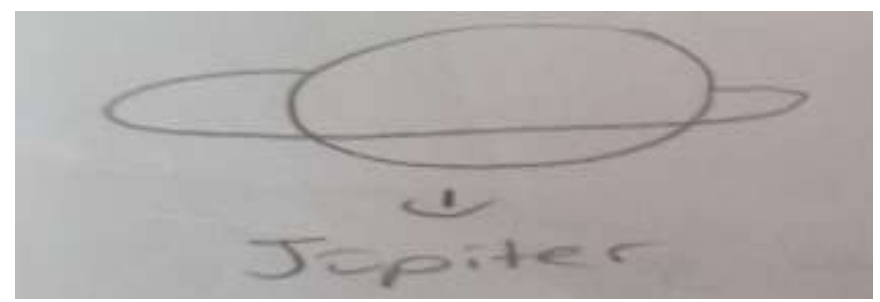

Tablo 3 incelendiğinde Güneş sistemi modeli çizen öğrenci sayıs1 22'dir. Bu kategoride değerlendirilen çizimlerin 5'i altınc1 sınıf, 11'i yedinci sınıf, 6's1 ise sekizinci sınıf öğrencisidir. $\mathrm{Bu}$ kategoride değerlendirilen çizimlerde öğrencilerin bilimsel olarak doğru kabul edilen bir çizim yaptıkları ve çizimlerde güneşin etrafında gezegenleri belirli bir sırada ve genellikle büyüklüklerine göre çizdikleri gözlenmiştir. Bu kategoride değerlendirilen çizimlere örnek aşağıda sunulmuştur.

Ö98 (6.sınıf): Güneş sistemi modeli çizimi

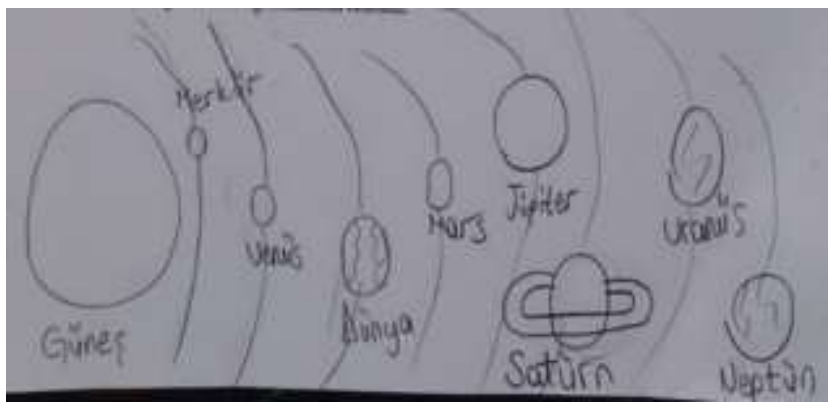

Tablo 3 incelendiğinde ortaokul öğrencilerinin daha az sayıda çizimlerinde, "Güneş etrafinda düz hat boyunca sıralanmış gezegen çizimi, güneş enerjisi paneli çizimi, yörünge çizimi ve yuvarlak çizimi"ne yer verdikleri görülmektedir. Bunun yanı sıra çalışmayı gerçekleştiren araştırmacılar tarafından herhangi bir kategoriye dahil edilmeyen çizimler anlamsız çizim olarak değerlendirilmiştir. Ayrıca 340 öğrenciden 44 öğrencinin hiç çizim yapmadığ görülmektedir.

\section{Öğrencilerin Güneş Sistemi İle İlgili Zihinsel Modelleri:}

Tablo 1'de belirlenen kriterler doğrultusunda, öğrencilerin veri toplama aracında yer alan birinci ve ikinci soruya 
verdikleri cevapların analizinden elde edilen veriler, öğrencilerin zihinsel modellerinin belirlenmesinde kullanılmıştır. Öğrencilerin “Güneş Sistemi” ile ilgili zihinsel modelleri Tablo 4'te sunulmuştur. Tablo 4 incelendiğinde, ortaokul öğrencilerinin Güneş sistemi ile ilgili bilimsel zihinsel modele sahip olmadığı söylenebilir. Tablo 4 incelendiğinde 340 ortaokul öğrencisinden 79 öğrencinin sentez zihinsel modele sahip olduğu, bu öğrencilerin 3'ünün beşinci sınıf, 18'inin altıncı sınıf, 31'inin yedinci sınıf ve 27 'sinin sekizinci sınıf olduğu görülmektedir. Öğrencilerde tespit edilen sentez zihinsel modellere örnekler aşağıda sunulmuştur.

Ö105 (6.sinıf): 1.sorunun cevab1: Gezegen isimleri. / 2.sorunun cevabi:

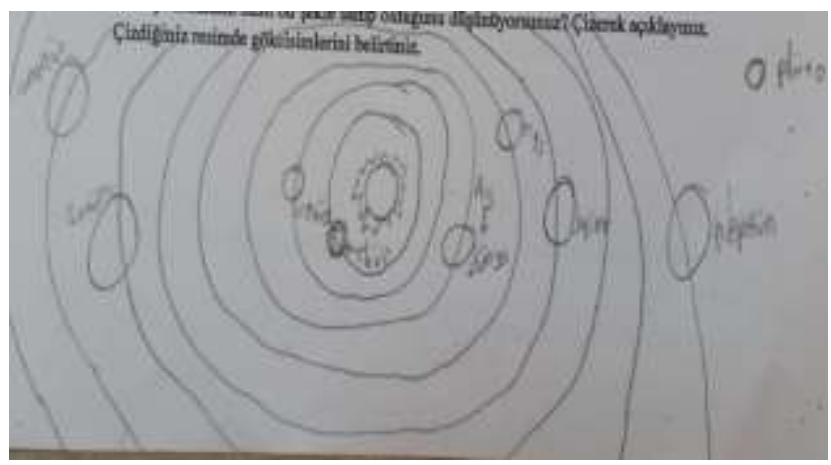

Ö105 sentez zihinsel model kategorisinde değerlendirilen öğrencilerdendir. Ö105'in bu kategoride değerlendirilmesinin nedeni 1.soruya vermiş olduğu cevabın eksik ikinci soruya vermiş olduğu cevabın ise doğru olmasıdır. Öğrenci 1.soruda Güneş sistemi nedir sorusuna gezegen isimleri şeklinde cevap verirken, 2.soruda "güneş sistemi modeli" çizimi gerçekleştirmiştir. Öğrencinin çiziminde gezegenlerin sırasına dikkat ettiği ancak gezegen büyüklüklerine dikkat etmediği görülmektedir. Ayrıca çalışmaya katılan öğrenciler arasında Güneş sistemi modeli çizip, bu model içerisinde Dünya'nın uydusu Ay'a yer veren tek öğrencidir. Öğrenci çiziminde dikkat çeken bir diğer nokta ise öğrencinin Pluton'a çiziminde yer vermesidir. Öğrenci Pluton'u diğer gezegenler gibi yörüngede çizmemiştir.

Ö337 (8.sınıf): 1.sorunun cevab1: Gezegen. /2.sorunun cevab1:

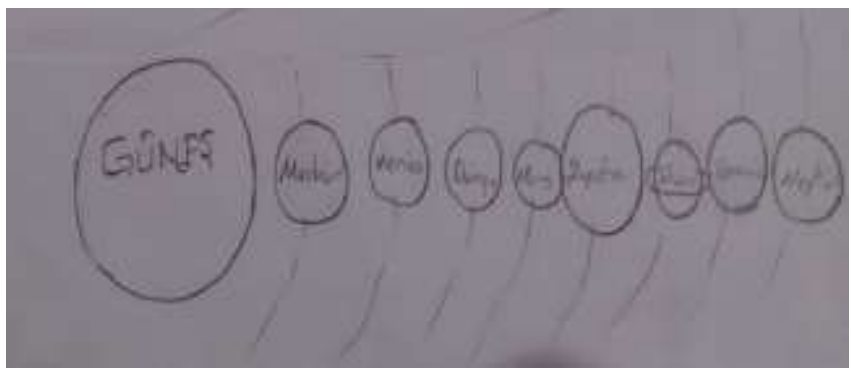

Ö337 sentez zihinsel model kategorisinde değerlendirilen öğrencilerdendir. Ö38 “Güneş sistemi nedir?" sorusuna gezegendir cevabını verirken, Güneş sistemini görsellerken, "Güneş etrafinda düz hat boyunca sıralanmış gezegen çizimi" gerçekleştirmiştir. Öğrenci çiziminde, gezegenlerin güneş etrafındaki sıralaması ve gezegen isimleri doğru iken, gezegenlerin büyüklüğüne dikkat etmemiştir.

Tablo 4. Öğrencilerin Güneş Sistemi ile ilgili Zihinsel Modelleri

\begin{tabular}{lllllllll}
\hline & 5. sinif & & 6. sinif & & 7.sinif & & 8. sinif \\
\hline Zihinsel Model Kategorileri & f & $\%$ & f & $\%$ & f & $\%$ & f & $\%$ \\
\hline Bilimsel Model & - & - & - & - & - & - & - & - \\
\hline Sentez Model & 3 & 5,9 & 18 & 18,9 & 31 & 34,1 & 27 & 26,2 \\
\hline İlkel Model & 27 & 52,9 & 61 & 64,3 & 51 & 56,1 & 65 & 63,1 \\
\hline Cevapsiz & 21 & 41,2 & 16 & 16,8 & 9 & 9,8 & 11 & 10,7 \\
\hline
\end{tabular}

Tablo 4 incelendiğinde, 340 öğrenciden 203 öğrencinin ilkel zihinsel modele sahip olduğu belirlenmiştir. Bu kategoride yer alan öğrencilerden 27'si beşinci sınıf, 61'i altıncı sınıf, 51'i yedinci sınıf ve 65'i sekizinci sınıfa devam etmektedir. Öğrencilerde tespit edilen ilkel zihinsel modellere örnekler aşağıda sunulmuştur.

Ö221 (7.sınıf): 1.sorunun cevabı: Güneş sistemi bir tür güneşten aldığı 1sıyı elektriğe çeviriyor. / 2.sorunun cevabı:

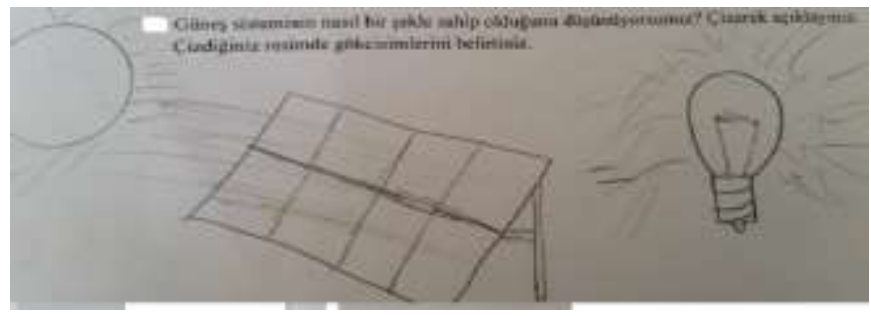

Ö221 ilkel zihinsel model kategorisinde değerlendirilen öğrencilerdendir. Öğrencinin bu kategoride değerlendirilmesinin sebebi Güneş sistemi ile ilgili betimleme ve görselleme durumunun bilimsel olmamasıdır.
Öğrenci cevabından da anlaşılacağı gibi, öğrencinin Güneş sistemini güneş enerji panelleri ile karıştırdığı görülmektedir.

Ö150 (6.sınıf): 1.sorunun cevabı: Güneşin Dünya'ya gelmesi

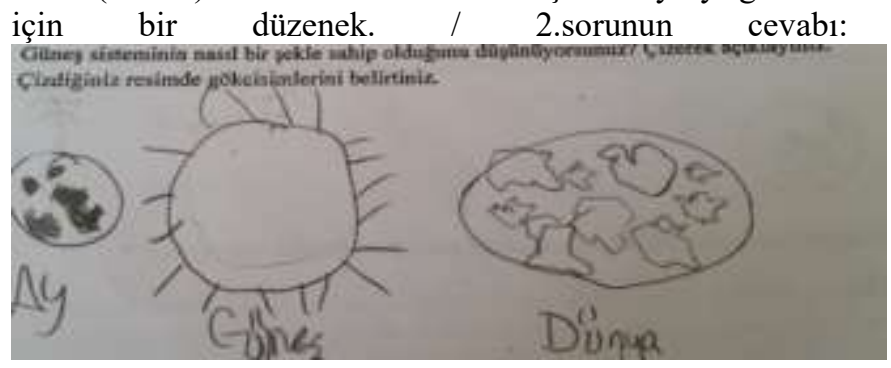

Ö150 ilkel zihinsel model kategorisinde değerlendirilen öğrencilerdendir. Öğrencinin bu kategoride değerlendirilmesinin sebebi güneş sistemi ile ilgili betimleme ve görselleme durumunun bilimsel olmamasıdır. 


\section{Sonuç}

Türkiye'de Fen Bilimleri Dersi öğretim programında 2018 yılından itibaren köklü değişikliklere gidilmiş olup, Güneş Sistemi ile ilgili konular daha önce 7.sınıflar programına dahil iken 2018 yılından itibaren 6.sınıf konuları arasında yer almıştır. Ayrıca eski programda yine Güneş sistemi konusu ikinci dönem konuları arasında iken değişiklikle beraber 6.sınıflarda ilk ünite kapsamında işlenen konular arasında yer almıştır. Araştırmanın 2017-2018 yılı ikinci döneminde gerçekleştirildiği düşünüldüğünde, 7.sınıf ve 8. sınıf öğrencileri Güneş sistemi konusunu okullarında işlemiş olup, 5. ve 6.sınıf öğrencileri ise okullarında Güneş sistemi ile ilgili bir öğretim faaliyeti içerisinde yer almamıştır. Sonuçlar bu durum dikkate alınarak yorumlanmıştır.

Ortaokul öğrencilerinin her sınıf düzeyinde, Güneş sistemi ile ilgili betimlemelerinde, s1klıkla gezegen veya gezegen ile ilişkili ifadeler kullandıkları görülmektedir. Alanda kullanılan Fen Bilimleri Dersi 7.sınıf ders kitapları incelendiğinde, Güneş sistemi ile aşağıda sunulan betimlemelerin yer aldığı görülmektedir.

“Güneş ve güneş çevresinde dolanan gök cisimlerinin oluşturduğu topluluğa Güneş sistemi denir. Güneş'in etrafinda gezegenler, onlarin uydularl, meteorlar ve kuyruklu yıldızlar dolanır. Güneş sistemindeki gezegenler birbirinden farkl özelliklere sahiptir." (MEB-7.sınıf Fen Bilimleri Ders kitab1- Mevsim Yayıncılık)

“Güneş sistemi, Güneş’ten ve onun etrafinda belirli yörüngelerde hareket eden gezegenlerden, uydulardan, kuyruklu yıldızlardan oluşan gök cisimleri topluluğudur." (MEB- 7.sınıf Fen Bilimleri Ders kitab1-Komisyon)

İncelenen ders kitaplarında Güneş sistemi ile ilgili betimlemelerde "meteor, uydu ve kuyruklu yıldı" kavramlarının yer aldığı görülmekte iken çalışmaya katılan öğrencilerden sadece altısı Güneş sistemi ile ilgili betimlemelerinde "uydu" kavramına yer vermiştir. Betimlemesinde "uydu" kavramına yer veren öğrenciler 5. ve 6.sınıf öğrencisidir. Bu sonuç öğrencilerin kavramlara ilişkin öğrenmelerini sadece okullarda gerçekleştirmediği şeklinde yorumlanabilir. Ekiz ve Akbaş (2005) tarafindan 6.sınıf öğrencileri ile gerçekleştirilen çalışma sonuçlarında da öğrencilerin Güneş Sistemini betimlerken benzer açıklamalara yer verdikleri ve öğrencilerin Güneş sistemi içerisinde gök cisimlerinin hareketleri ile ilgili yanlış anlamalara sahip olduğu belirlenmiştir. Öğrenci betimlemelerinde dikkat çeken bir diğer nokta ise, öğrencilerin Güneş sistemi ile ilgili açıklamalarında "gezegenlerin sıralaması / gezegen topluluğu" gibi ifadeleri kullanmalarıdır. Bu sonuç öğrencilerin güneş dahil Güneş sistemi içerisinde yer alan tüm gök cisimlerini gezegen olarak değerlendirmesi şeklinde yorumlanabilir. Benzer bir sonuç Şenel-Çoruhlu (2013) tarafindan gerçekleştirilen çalışma ile ortaya konulmuştur. Şenel-Çoruhlu (2013) çalışmasında, yedinci sınıf öğrencilerinin "Güneş sistemi içerisinde yer alan güneş bir gezegendir." yanılgısına sahip olduğu sonucuna ulaşmıştır.

Ortaokul öğrencilerinin güneş sistemi ile ilgili görselleme durumları incelendiğinde ise, bilimsel olarak doğru kabul edilebilecek çizimlerin oldukça az olduğu görülmüştür. Öğrencilerin sıklıkla "Güneş etrafında düz bir hat boyunca sıralanmış gezegen çizimi / Güneş etrafında dağınık gezegen çizimi / Güneş merkezli yörünge çizimi / Üçlü model çizimi”" gerçekleştirdiği görülmektedir. Yine bu çizimlerin 6,7 ve 8.sınıf düzeyinde birbirine yakın değerlerde olduğu görülmektedir. Öğrencilerin Güneş sistemi ile ilgili görselleme durumları incelendiğinde, gökcisimlerinin büyüklüklerine ve boyutlarına dikkat edilmediği belirlenmiştir. Öğrenci çizimlerinde Güneş ve Dünya'nın büyüklüklerinin birbirine yakın çizildiği veya tüm gezegenlerin birbiriyle aynı büyüklükte çizildiği görülmektedir. Bazı öğrenci çizimlerinde dikkat çeken bir diğer nokta ise, gezegen yörüngelerinin çizimlerde belirtilmemesidir. Bu durum, öğrencilerin, gezegenlerin hareketsiz olduğunu düşündükleri şeklinde yorumlanabilir. Öğrencilerin Güneş sistemi ile ilgili yanlış ve eksik çizim yapmasının sebeplerinden birisi ders kitapları olabilir. İncelenen ders kitaplarında Güneş sistemi ile ilgili yanlış veya eksik görsellerin kullanıldığı görülmektedir. $\mathrm{Bu}$ görsellere örnekler aşağıda sunulmuştur.

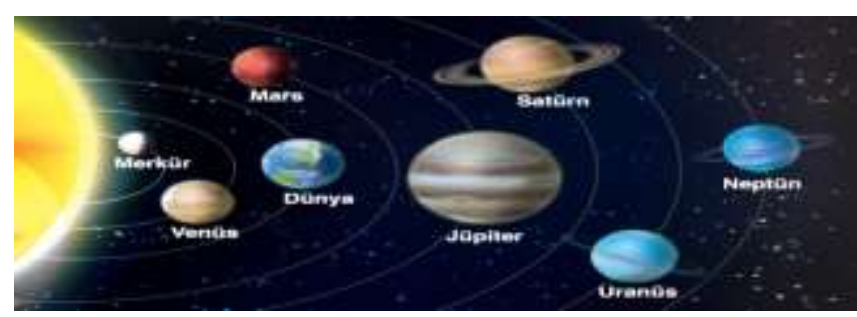

Şekil 1. (MEB-7.sınıf Fen Bilimleri Ders kitabı- Mevsim Yayıncilik, s.250)

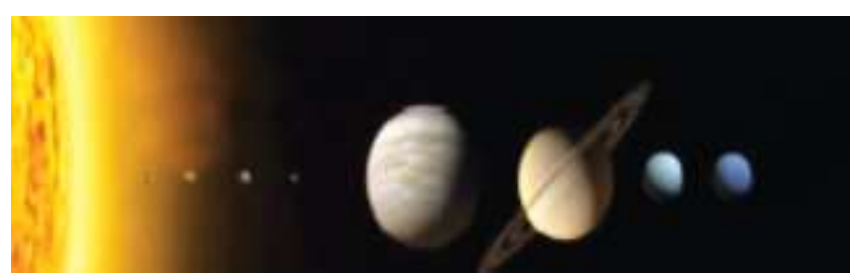

Şekil 2. (MEB- 7.sınıf Fen Bilimleri Ders kitabı-Komisyon, s.260)

Kitaplarda Güneş sistemi ile ilgili betimlemelerde her ne kadar "uydu, meteor, kuyruklu yıldız" kavramları yer alsa da, görsellerde bu kavramlara ait çizimlerin kullanılmadığ görülmektedir. Ayrıca yine ders kitaplarında yer alan modelleme etkinliklerinde de bu yapılara yer verilmediği, sadece merkezde Güneş’in yer aldığ 1 , gezegenlerin Güneş’e olan uzaklıklarına göre sıralandığı görülmektedir. Ortaokul öğrencilerinin Güneş sistemi ile ilgili görsellemeleri değerlendirildiğinde, alan yazında yer alan çalışmalar ile benzer sonuçlar elde edildiği görülmektedir. Çalışmadan elde edilen "Güneş etrafinda düz bir hat boyunca sıralanmış gezegen çizimi”" Calderon-Canales vd.(2013) ve Sharp ve Kuerbis (2005) tarafından gerçekleştirilen çalışmalarda da ortaya konulmuştur. Çalışmadan elde edilen bir diğer sonuç ise ortaokul öğrencilerinin Güneş sisteminde yer alan yapıları doğru çizse de, çizimlerinde gök cisimlerinin büyüklüklerine dikkat etmemeleridir. Bu sonuç Uluç ve arkadaşları (2016) tarafından gerçekleştirilen çalışma sonuçları ile uyumludur.

Ortaokul öğrencilerinin Güneş sistemi ile ilgili zihinsel modelleri incelendiğinde; hiçbir sınıf seviyesinde bilimsel zihinsel modele sahip öğrencinin yer almadığı görülürken her sınıf seviyesinde sentez modele sahip öğrencinin yer 
aldığı görülmektedir. Bu sonuç alan yazında yer alan çalışma sonuçları ile benzerlik göstermektedir. Aksan ve Çelikler (2015) gerçekleştirdikleri çalışmada, 8.sınıfa devam eden öğrencilerin Güneş sistemi ile ilgili sentez modele sahip oldukları sonucuna ulaşmışlardır. Sharp (1996), tarafından gerçekleştirilen çalışmada da, öğrenciler ile gerçekleştirilen görüşmeler sonucunda, öğrencilerin Güneş sistemi ile ilgili sentez zihinsel modellere sahip oldukları belirlenmiştir. Sharp ve Kuerbis (2005) tarafından gerçekleştirilen çalışma sonucunda da, Güneş sistemi ile ilgili dokuz farklı zihinsel model tespit edilmiştir. $\mathrm{Bu}$ modellerin daha çok sentez modeller şeklinde olduğu görülmüştür. Bilindiği gibi sentez modellerin oluşabilmesi için öğrenci cevaplarında hem bilimsel hem ilkel cevapların yer alması gerekmektedir. Sentez model kategorisinde 5.sinıf düzeyinde az sayıda öğrenci yer alırken 6.sınıf düzeyinde 18 öğrenci yer almaktadır. 6.sınıfa devam eden bu öğrenciler okullarda doğrudan Güneş sistemi ile ilgili bir öğretim programı içerisinde yer almamışlardır. Yine benzer bir durum 7 ve 8.sınıflar için geçerlidir. Bu sınıflarda ise okullarda Güneş sistemi konusu işlenmiş olmasına rağmen öğrencilerin sentez model ve ilkel model kategorilerinde yer almaları zihinsel modellerin oluşumunda öğretim programları kadar başka diğer faktörlerin de etkili olduğu sonucuna götürür.

Astronomi ile ilgili kavramlar ele alındığında, öğrencilerin çoklu bakış açısı ile olayları veya nesneleri farklı açılardan incelemesi gerektiği görülmektedir (Parker ve Heywood, 1998 akt: Barnett, MaKinster ve Hansen, 2001). Ayrica astronomi öğrencilerin üç boyutlu uzaydaki nesneler arasındaki, karmaşık ilişkileri ve dinamikleri anlamalarını gerektirir. Öğrencilerin astronomi kavramlarını anlamalarını geliştirmek için sadece bir bakış açısı-Dünya'nın bakış açısıvardır. Astronominin üç boyutlu yapısına rağmen, çoğu ders materyalinde iki boyutlu resimler ya da grafikler yer almaktadır (Barnett vd. 2001). Bu nedenle öğrencilerin gök cisimleri ile ilgili farklı bir bakış açısı geliştirebilmeleri ve zihinsel modellerinin bilimsel model kategorisinde nitelendirilebilmesi için, öğrencilerin çok sayıda duyu organına hitap edecek öğrenme ortamları tasarlanarak dersler işlenmelidir. Bu noktada, derslerde, tam ve doğru olarak hazırlanmış üç boyutlu modellerin kullanılması, üç boyutlu modellerin öğrenciler tarafindan oluşturulması veya arttırılmış gerçeklik uygulamalarına yer verilmesi önerilebilir. Öğrencilerin, gözlem ve araştırma yapmalarını sağlama, yerinde görme ve öğrenme ve işin uzmanı bireylerden bilgi almasına olanak sağlayan okul dışı öğrenme ortamlarından (Planetaryum, uzay kampı vb.) yararlanılabilir. Ders kitaplarında Güneş sistemi ile ilgili betimleme ve görselleme durumlarının birbiri ile uyumlu olması sağlanabilir. Ayrıca ders kitaplarında Güneş sistemi ile ilgili kullanılan görsellerin seçimine dikkat edilerek, hatalı görsel (Güneş etrafında düz bir hat boyunca sıralanmış gezegen çizimi, gazsal gezegenlerin halkasının olmaması vb.) sunumundan kaçınılabilir. Bu araştırmada öğrencilerin Güneş sistemini betimleme ve görselleme durumları ele alınmış olup, farklı çalışmalarda, gerçekleştirilecek görüşmeler ile zihinsel modellerin kaynakları açık bir şekilde tespit edilebilir. $\mathrm{Bu}$ çalışmada 5.sınıflarda tespit edilen bilimsel olmayan zihinsel modellerin diğer sınıflarda da açığa çıktığı gözlenmiştir. Bu durum, yanlış öğrenilen kavramların sınıf seviyesi ilerlese de, dirençli yapısından dolayı devamlılık gösterdiği şeklinde yorumlanabilir. Bu nedenle, konu öğretiminde Güneş sistemi ile ilgili alan yazında yer alan alternatif kavramlara dikkat edilmesi ve öğretmenlerin kendilerinde var olan alternatif kavramları öğrencilerine aktarabilecekleri göz önünde bulundurulduğunda, benzer çalışmaların öğretmen adayları ile gerçekleştirilmesi önerilebilir.

\section{Kaynakça}

Aksan, Z., \& Çelikler, D. (2015). Determining the level of knowledge and mental models of secondary school students regarding the solar system, Journal of Environment and Earth Science, 5(13), 15-21.

Ayvac1, H. S., Bebek, G., Atik, A., Keles, C. B., \& Özdemir, N. (2016). Öğrencilerin sahip oldukları zihinsel modellerin modelleme süreci içerisinde incelenmesi: hücre konusu örneği. Dicle Üniversitesi Ziya Gökalp Eğitim Fakültesi Dergisi, 28, 175-188. https://doi.org/10.14582/DUZGEF.711

Babaoğlu, G., \& Keleş, Ö. (2018). 6. sınıf öğrencilerinin "yıldız", "gezegen" ve "ay, dünya ve güneş" kavramlarına yönelik algılarının belirlenmesi. Karaelmas Ĕ̆itim Bilimleri Dergisi, 6(1), 127-145.

Barnett, M., MaKinster, J. G., \& Hansen, J. A. (2001). Exploring elementary students' learning of astronomy through model building. This paper was presented at the annual meeting of the American Educational Research Association, Seattle, WA. April $10-14$. http://www.stanford.edu/dept/SUSE/projects/ireport/arti cles/3D/astronomy\%20for \%20elementary.pdf sayfasından erişilmiştir.

Calderon-Canales, E., Flores-Camacho, F., \& GallegosCazares, L. (2013) Elementary students' mental models of the solar system. Astronomy Education Review. 12(1), $1-17$.

Can, S., \& Görecek-Baybars, M. (2018). Secondary school students' mental models regarding the space. Journal of Education and Learning, 7(2), 122-135. https://doi.org/10.5539/jel.v7n4p122

Çelik, M., \& Tekbıyık, A. (2016). İlkokul ikinci sınıf öğrencilerinin dünya ve uzay kavramlarına yönelik zihinsel modelleri ve imajları. International Journal of Eurasia Social Sciences, 7(25), 271-289.

Coll, R. K., \& Treagust, D. F. (2003). Investigation of secondary school, undergraduate and graduate learners' mental models of ionic bonding. Journal of Research in Science Teaching, 40(5), 464-486. https://doi.org/10.1002/tea.10085

De Posada, J. M. (1997). Conceptions of high school students concerning the internal structure of metals and their electric conduction: Structure and Evolution. Science Education, 81(4), 445-467. https://doi.org/10.1002/(SICI)1098-

237X(199707)81:4<445::AID-SCE5>3.0.CO;2-C

Demircioğlu, H., Vural, S., \& Demircioğlu, G. (2012). "REACT" stratejisine uygun hazırlanan materyalin üstün yetenekli öğrencilerin başarısı üzerinde etkisi. Ondokuz Mayls Üniversitesi Eğitim Fakültesi Dergisi, 31(2), 101144. 
Ekiz, D., \& Akbaş, Y. (2005). İlköğretim 6. sınıf öğrencilerinin astronomi ile ilgili kavramları anlama düzeyi ve kavram yanılgıları. Milli Ĕgitim Dergisi, 165, 61-78.

Franco, C., \& Colinvaux, D. (2012). Grasping mental models. In J. K. Gilbert \& C. J. Boulter (Eds.), Developing models in science education (93-118). New York, NY: Springer Netherlands. https://doi.org/10.1007/978-94-010-0876-1

Görecek-Baybars, M. (2018). Fen bilgisi öğretmen adaylarının metallerin elektrik iletkenliği ile ilgili zihinsel modellerinin belirlenmesi. Eğitimde Kuram ve Uygulama, 14(1), 36-47. https://doi.org/10.17244/eku.328952

Greca, I. M., \& Moreira, M.A. (2000). Mental models, conceptual models, and modeling. International Journal of Science Education, 22, 1-11.

Harrison, A. G. (2001). How to teachers and textbook writers model scientific ideas for students. Research in Science Education, 31, 401-435.

Harrison, A. G., \& Treagust, D. F. (2000). A typology of school science models. International Journal of Science Education, 22, 1011-1026.

İyibil, Ü.G. (2010). Farklı programlarda öğrenim gören ögretmen adaylarının temel astronomi kavramlarını anlama düzeylerinin ve ilgili kavramlara ait zihinsel modellerinin analizi. Yayımlanmamış Yüksek Lisans Tezi, Fen Bilimleri Enstitüsü, Karadeniz Teknik Üniversitesi, Trabzon.

İyibil, Ü., \& Sağlam-Arslan, A. (2010). Fizik öğretmen adaylarının yıldız kavramına dair zihinsel modelleri, Necatibey Ĕ̆itim Fakültesi Dergisi, 4(2), 25-46.

Jabot, M., \& Henry, D. (2007). Mental models of elementary and middle school students in analyzing simple battery and bulb circuits. School Science and Mathematics, 107, 371-381.

Karasar, N. (2011). Bilimsel araştırma yöntemi; kavramlarilkeler-teknikler, 22.basım, Nobel Kitap, Ankara.

Kibble, B. (1999). How do you picture electricity? Physics Education, 34(4), 226-229.

Kurnaz, M. A., \& Değermenci, A. (2012). 7. Sınıf ögrrencilerinin güneş, dünya ve ay ile ilgili zihinsel modelleri. Illkögretim Online, 11(1), 137-150

Kurnaz, M. A., Tarakçı, F., Aydın, A., \& Pektaş, M. (2013). Elektriklenme, yıldırım ve şimşek ile ilgili öğrenci zihinsel modellerinin incelenmesi. Uşak Üniversitesi Sosyal Bilimler Dergisi, 6(4), 33-51.

Lee, C. B., Jonassen, D., \& Teo, T. (2011). The role of model building in problem solving and conceptual change. Interactive Learning Environments, 19(3), 247-265.

MEB (2017). 7.sınıf Fen Bilimleri Ders Kitabı, Mevsim Yayıncilik.

MEB (2017). 7.sınıf Fen Bilimleri Ders Kitabı, Komisyon.

Norman, D. A. (1983). Some observations on mental model. Human-computer interaction, 241-244, Morgan Kaufmann Publishers Inc. San Francisco.
Örnek, F. (2008). Models in science education: applications of models in learning and teaching science, International Journal of Environmental \& Science Education, 3(2), $35-45$.

Sharp, J., \& Kuerbis, P. (2005). Children's ideas about the solar system and the chaos in learning science, International Journal of Science Education, 90, 124.

Sharp, J. G. (1995). Children's astronomy: Implications for curriculum developments at key stage 1 and the future of infant science in England and Wales. International Journal of Early Years Education, 3(3), 17 - 49.

Sharp, J. G. (1996). Children's astronomical beliefs: A preliminary study of year 6 children in south-west England. International Journal of Science Education, 18(6), 685-712.

Saçkes, M., \& Korkmaz, H. İ. (2015) Anaokulu çocuklarının dünyanın şekline ilişkin zihinsel modelleri. Ilköğretim Online, 14(2), 734-743.

Stratford S. J., Krajcik, J., \& Soloway E. (1988). Secondary students' dynamic modeling processes: analyzing, reasoning about, synthesizing, and testing models of stream ecosystems. Journal of Science Education and Technology, 7(3), 215-234.

Şenel-Çoruhlu, T. (2013). Güneş sistemi ve ötesi uzay bilmecesi ünitesinde zenginleştirilmiş $5 E$ Öğretim Modeli'ne göre geliştirilen rehber materyallerin etkililiğinin belirlenmesi. Yayımlanmamış doktora tezi, Eğitim Bilimleri Enstitüsü, Karadeniz Teknik Üniversitesi, Trabzon.

Treagust, D. F., Chittleborough, G., \& Mamiala, T. L. (2002). Students' understanding of the role of scientific models in learning science. International Journal of Science Education, 24(4), 357-368.

Uluç, K., Yetkiner, R., Taner, M. S., Kaynar, S., Okuyan, O., Eryılmaz-Kılıç, ... Özıșı, T. (2016). Tug bitom eğitsel faaliyetlerinin $M E B$ ögrencilerinin astronomi kavramlarını anlama düzeyine etkisi. Ulusal Astronomi Kongresi, Sözlü Bildiri, Erzurum.

Ünal-Çoban, G. (2009). Modellemeye dayall fen ögretiminin öğrencilerin kavramsal anlama düzeylerine, bilimsel süreç becerilerine, bilimsel bilgi ve varlık anlayışlarına etkisi: 7. Sınıf ışık ünitesi örneği. Yayınlanmamış Doktora Tezi, Eğitim Bilimleri Enstitüsü, İzmir.

Vosniadou, S., \& Brewer, W. F. (1992). Mental models of the earth: A study of conceptual change in childhood. Cognitive Psychology, 24(4), 535-585.

Vosniadou, S. (1994). Capturing and modelling the process of conceptual change. Learning and Instruction, 4(1), 4569.

Yıldırım, A., \& Şimşek, H. (2008). Sosyal Bilimlerde Nitel Araştırma Yöntemleri, (6.Baskı). Ankara: Seçkin Yayıncilık.

Yılmaz, E., Türkoğuz, S., \& Şahin, M. (2014). Güneş sistemi ve uzay konularına yönelik kavram yanılgılarının günlük yaşama etkisi üzerine öğretmen görüşleri. Buca Eğitim Fakültesi Dergisi, 37, 37-44. 
Yürümezoğlu, K., \& Çökelez, A. (2010). Akım geçiren basit bir elektrik devresinde neler olduğu konusunda öğrenci görüşleri. Türk Fen Eğitimi Dergisi, 7(3), 147-166. 